\title{
The Effects of Nicotine on the Incisive Teeth and Expression of Vimentin in Rats
}

\author{
Efectos de la Nicotina sobre los Dientes Incisivos y la Expresión de Vimentina en Ratas
}

\author{
E. R. Faruk*; Deveci, E.**; Kalkanl, S.**** \& Deveci, B.*
}

FARUK. E. R.; DEVECI, E.; KALKANLI, S. \& DEVECI, B. The effects of nicotine on the incisive teeth and expression of vimentin in rats. Int. J. Morphol., 31(2):516-519, 2013.

SUMMARY: Nicotine is an alkaloid toxic effects of oral cavity. In this study,14 adult Sprague-Dawley rats weighing 230-260 $\mathrm{mg}( \pm 10 \mathrm{mg})$ were used as experimental animal. The rats of experimental group $(\mathrm{n}=6)$ were nicotinized systemically with nicotine sulphate, $2 \mathrm{mg} / \mathrm{kg}$ subcutaneously, daily in period of 28 days. Pulp, alveolar bone tissue, periodontal membrane and gingival epithelial junction were investigated in these regions in incisive teeth longitudinal cross-section. Thinning of the collagen fibers in the pulp tissue, vascular congestion, and inflammatory cell infiltration were observed. Mesenchymal tissues that is stained positive for vimentin lay underneath the epithelium. A strong expression of vimentin can be observed in formed periodontal ligament.

KEY WORDS: Nicotine; Rat; Vimentin.

\section{INTRODUCTION}

Nicotine is an alkaloid from the oxygen-free alkaloid group, which is the major psychoactive component of cigarette smoke that is highly addictive if inhaled via binding to nicotinic cholinergic receptors in the brain and releasing neurotransmitters such as dopamine and by causing neuroadaptation (Henningfield \& Goldberg, 1988). Many studies have investigated nicotine`s cellular and molecular effects. Investigations of nicotine's effect on cultured cells suggest that it can influence bone resorption and apposition (Yuhara et al., 1999). Nicotine causes an increase in the expression of the cyclo-oxygenase-2 (COX-2) gene and prostaglandin E2 (PGE2) release in human gingival fibroblasts in a time and dose-dependent manner (Nakao et al., 2009). Paulson et al. (2009), demonstrated a direct relationship between nicotine dose and decrease of the fetal weight, number of resorptions and malformations, embryotoxicity and intrauterine growth retardation. It is now accepted that an important causing factor of intrauterine growth retardation in smoking mother's conceptuses is fetal hypoxia and/or ischemia due to reduction of the uteroplacental blood flow by both carbon monoxide and nicotine of the cigarette (Donnenfeld et al., 1993). The present investigation revealed that cigarette smoke might provoke alterations at cellular level, even in a passive absorption.

\section{MATERIAL AND METHOD}

The study protocol was approved by the Animal Research Committee of Dicle University, Turkey. 14 adult Sprague-Dawley rats weighing $230-260 \mathrm{~g}( \pm 10 \mathrm{~g})$ were used as experimental animal.The animals were group- housed (7per cage) under standard conditions in the Animal Health and Research Center of Dicle University . The animals were fed ad libitum with water and standard laboratory animal diet, under the care of trained wardens. The rats were divided into 2 groups as: The rats of experimental group $(n=6)$ were nicotinized systemically with nicotine sulphate (Sigma, Aldrich), $2 \mathrm{mg} / \mathrm{kg}$ subcutaneously, daily in period of 28 days. The rats of group control $(\mathrm{n}=6)$ was used as control and did not receive NIC, but were maintained in similar environment and food.

Tissue Preparation for Light Microscopy. At the end of the study, animals were sacrified decapitation. The maxillary

\footnotetext{
* Near East University, Faculty of Dentistry Restorative Dentistry, North Cyprus.

** Department of Histology and Embryology, School of Medicine, Dicle University, Diyarbakir, Turkey.

*** Department of Immunology, Faculty of Medicine, Dicle University Diyarbakir, Turkey.
} 
regions were dissected under ketamine hydrochloride anesthesia. The samples were fixed with neutral buffered formalin solution and decalcified with 5\% EDTA (Ethylene-diamine-tetraacetic acid). After preservation, nasal samples were directly dehydrated in a graded series of ethanol and embedded into paraffin wax. 4-6 $\mathrm{mm}$ sections were cut with microtome (Rotatory Microtome, Leica, RM 2265 , Germany) and mounted on the coated slides. The sections were stained with H-E, and Trichrome-Masson in order to be observed under light microscope (Nikon Eclipse 80i).

Immunohistochemistry stain. Phosphate-buffered solution (PBS, pH 7.2) were washed $3 \times 5$ minutes.Citrate buffer, tissue sections were antigenically masked for the abolition of the environment and $2 \times 5$ minutes in a microwave oven,waited outside for 10 minutes. The slides were washed in PBS, and marked the boundaries of tissue on the hydrophobic pen. Three percent hydrogen peroxide were dropped on the tissue and allowed to stand for 15 minutes. Sections were washed in PBS at room temperature and humid 80 min were stained with antibodies to vimentin in the primary. Washed with PBS. Secondary antibodies and streptavidin-peroxidase complex, 30 minutes, stained. Diaminobenzidine as the chromogen (DAB) were stained for 3-5 minutes. One minute with Harris hematoxylin staining was the opposite.

\section{RESULTS}

Histological analysis of nicotine-treated group and the control group were compared with the incisive teeth. Pulp, alveolar bone tissue, periodontal membrane and gingival epithelial junction were investigated in these regions, incisive teeth longitudinal cross-section, thinning of the collagen fibers in the pulp tissue, vascular congestion, and inflammatory cell infiltration were observed (Figure 1A). Periodontal membrane, expansion of blood vessels, red blood cells showed intense perivascular infiltration (Figure 1B). Fibroblast cells, collagen fibers, characterized by hyperplasia of the intermediate stroma expansion was seen in a different direction (Figure 1C). Beginning of the periodontal membrane and alveolar bone region drew attention to the ongoing increase in osteoclastic cells. Nicotine can be applied to another section of the group, gingival epithelium cells hypertrophy and an increase in mitotic activity was observed. Mononuclear cell infiltration of the gingival connective tissue junction, and a thickening of collagen fiber bundles were seen.

These results showed that the morphological and histological nicotine $2 \mathrm{mg} / \mathrm{g}$ administration fibrous periodontal membrane and alveolar bone disorder is caused by degeneration of the cells. pulp tissue, vimentin expression was intense in the cells of mesenchymal origin.

Cytokeratin change with the change of shape due to cell degeneration were observed (Figure 1D). The group treated with nicotine, cement and vimentin expression was observed in the periodontal membrane density irregularities along the collagen fibers were observed (Figure 1E). Mesenchymal tissues that is stained positive for vimentin lay underneath the epithelium. Astrong expression of vimentin can be observed in formed periodontal ligament; negative expression of vimentin was observed in alveolar bone osteoblasts (Figure 1F).

\section{DISCUSSION}

Nicotine is a major component of tobacco smoke. Tobacco smoking is probably the most important periodontitis, auditable environmental risk factor, which is shown to cause inflammatory changes (Palmer \& Scott, 1999). Typically for cells of mesenchymal origin, periodontal ligament fibroblasts labelled for vimentin. By analogy with other tissues, the accumulation of vimentin may be related to mechanical loading. There is evidence to suggest that it accumulates in cartilage and fibrocartilage and endothelial cells in response to mechanical loading (Ralphs et al., 1992; Schnittler et al., 1993; Benjamin et al., 1994). In rats, daily administration of nicotine adversely affects the periodontal tissues in a dose-dependent manner. Nicotine bone-forming cells and cellular proliferation and collagen synthesis (Lenz et al., 1990). This is caused by inadequacies in the dentin matrix, odontoblast function can be expressed in danger.

In vitro studies have shown nicotine negatively affected osteoblasts (Yuhara et al.), inhibited gingival fibroblast growth and production of fibronectin and collagen, while promoting collagen breakdown (Tripton \& Dabbous, 1995). It also affects periodontal ligament fibroblasts (Pinto et al., 2002) and stimulates osteoclasts activity (Yuhara et al.; Henemyre et al., 2003). The group treated with nicotine, cement and vimentin expression was observed in the periodontal membrane density irregularities along the collagen fibers were observed. Nicotine, soft tissues such as gingiva and periodontal ligament fibroblasts growing vascular congestion and a negative impact in terms of activity. As a result, the ability of nicotine change the fibroblast metabolism by affecting the synthesis of extracellular matrix molecules could imagine. 


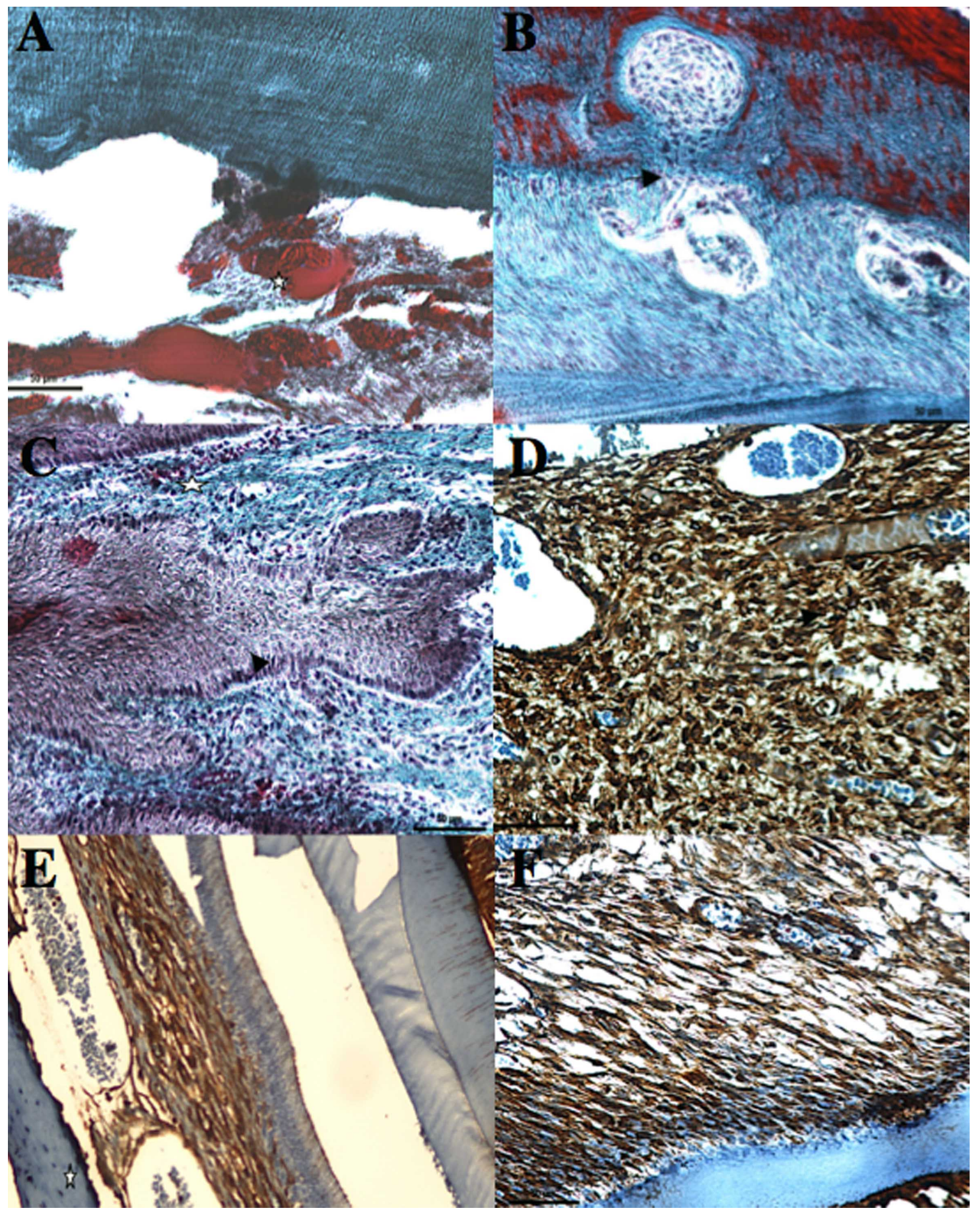

Fig. 1. A). Thinning of the collagen fibers in the pulp tissue, vascular congestion (*) and inflammatory cell infiltration (Masson Bar $50 \mu \mathrm{m})$. B). Dilatation of blood vessels and free eritrocytes, infiltration in perivascular area (arrow), degenerative cells in peridontal

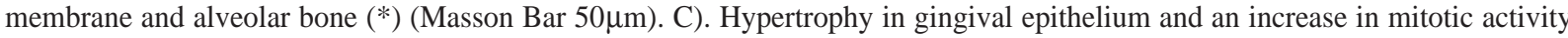
(arrow). Mononuclear cell infiltration of the gingival connective tissue junction (*) (Masson Bar 50 $\mu$ m). D). An increase in the

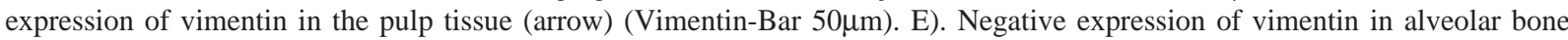

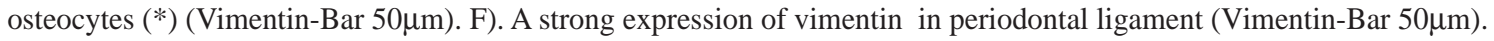


FARUK. E. R.; DEVECI, E.; KALKANLI, S. \& DEVECI, B. Efectos de la nicotina sobre los dientes incisivos y la expresión de vimentina en ratas. Int. J. Morphol., 31(2):516-519, 2013.

RESUMEN: La nicotina es un alcaloide con efectos tóxicos sobre la cavidad oral. En este estudio, se utilizaron como animales de experimentación, 14 ratas Sprague-Dawley adultas con un peso entre 230-260 mg $( \pm 10 \mathrm{mg})$. Las ratas del grupo experimental $(\mathrm{n}=6)$ fueron expuestas a nicotina sistémicamente con sulfato de nicotina, $2 \mathrm{mg} / \mathrm{kg}$ vía subcutánea al día, durante 28 días. Fueron estudiadas la pulpa, tejido óseo alveolar, membrana periodontal y la unión del epitelio gingival en los dientes incisivos en secciones transversales y longitudinales. Se observó un adelgazamiento de las fibras de colágeno, congestión vascular e infiltración de células inflamatorias en el tejido de la pulpa. Los tejidos mesenquimales que tiñeron positivamente para vimentina se ubicaron debajo del epitelio. Una fuerte expresión de vimentina se pudo observar en el ligamento periodontal.

PALABRAS CLAVE: Nicotina; Rata; Vimentina.

\section{REFERENCES}

Benjamin, M.; Archer, C. W. \& Ralphs, J. R. Cytoskeleton of cartilage cells. Microsc. Res. Tech., 28(5):372-7, 1994.

Donnenfeld, A. E.; Pulkkinen, A.; Palomaki, G. E.; Knight, G. J. \& Haddow, J. E. Simultaneous fetal and maternal cotinine levels in pregnant women smokers. Am. J. Obstet. Gynecol., 167(3 Pt. 1):781-2, 1993.

Henemyre, C. L.; Scales, D. K.; Hokett, S. D.; Cuenin, M. F.; Peacock, M. E. \& Parker, M. H. Nicotine stimulates osteoclast resorption in a porcine marrow cell model. J. Periodontol., 74)10):1440-6, 2003.

Henningfield, J. E. \& Goldberg, S. R. Progress in understanding the relationship between the pharmacological effects of nicotine and human tobacco dependence. Pharmacol. Biochem. Behav., 30(1):217-20, 1988.

Lenz, L. G.; Galvin, R. J. S. \& Ramp, W. K. Nicotine inhibits collagen synthesis and alkaline phosphatase activity but stimulates DNA synthesis in osteoblast-like cells. J. Bone Miner. Res., 5:S159, 1990.

Nakao, S.; Ogata, Y. \& Sugiya, H. Nicotine stimulates the expression of cyclooxygenase-2 mRNA via NFkappaB activation in human gingival fibroblasts Arch. Oral Biol., 54(3):251-7, 2009.

Palmer, R. M.; Scott, D. A.; Meekin, T. N.; Poston, R. N.; Odell, E. W. \& Wilson, R. F. Potential mechanisms of susceptibility to periodontitis in tobacco smokers. J. Periodontal Res., 34(7):363-9, 1999.

Paulson, R.; Shanfeld, J.; Sachs, L.; Prince, T. \& Paulson, J. Effect of smokeless tobacco on the development of the CD-1 mouse fetus. Teratology, 40(5):483-94, 1989.

Pinto, J. R.; Bosco, A. F.; Okamoto, T.; Guerra, J. B. \& Piza, I. G. Effects of nicotine on the healing of extraction sockets in rats. A histological study. Braz. Dent. J., 13(1):3-9, 2002.
Ralphs, J. R.; Tyers, R. N. \& Benjamin, M. Development of functionally distinct fibrocartilages at two sites in the quadriceps tendon of the rat: the suprapatella and the attachment to the patella. Anat. Embryol. (Berl.), 185(2):1817, 1992.

Schnittler, H. J.; Schmandra, T. \& Drenckhahn, D. Experimentelle Induction von intermediar filament proteinen durch hydrostatischen Druck. Ann. Anat., 175:48, 1993.

Tripton, D. A. \& Dabbous, M. K. Effects of nicotine on proliferation and extracellular matrix production of human gingival fibroblasts in vitro. J. Periodontol., 66(12):1056-64, 1995.

Yuhara, S.; Kasagi, S.; Inoue, A.; Otsuka, E.; Hirose, S. \& Hagiwara, $\mathrm{H}$. Effects of nicotine on cultured cells suggest that it can influence the formation and resorption of bone. Eur. J. Pharmacol., 383(3):387-93, 1999.

\section{Correspondence to: \\ Engin Deveci \\ Dicle University \\ Medical Faculty \\ Histology and Embryology Dept. \\ 21280 Diyarbakır \\ TURKEY}

Email:engindeveci64@gmail.com

Received: 01-11-2012

Accepted: 14-01-2013 